\title{
Stepped-wedge cluster randomised controlled trials: some variations on the common design
}

\author{
Karla Hemming ${ }^{*}$, Alan Girling \\ From 2nd Clinical Trials Methodology Conference: Methodology Matters \\ Edinburgh, UK. 18-19 November 2013
}

Stepped wedge cluster randomised trials (SW-CRTs) are being used with increasing frequency in health service evaluation. Conventionally, these studies are designed with equally spaced steps, with an equal number of clusters randomised at each step, and data collected at each and every step.

Here we introduce several variations on this design and consider implications for power. One modifiction we consider is where the number of clusters varies at each step, or where at some steps data are not collected. We show that the parallel CRT with staggered, but balanced randomisation, can be considered a special case of the incomplete SW-CRT. And, we extend these designs to allow for multiple layers of clustering, for example wards within a hospital. Building on results for complete designs, power and detectable difference are derived using Wald-test and obtaining the variance-covariance matrix of the treatment effect assuming a generalised linear mixed model. These variations are illustrated by several real examples.

Published: 29 November 2013

doi:10.1186/1745-6215-14-S1-P15

Cite this article as: Hemming and Girling: Stepped-wedge cluster

randomised controlled trials: some variations on the common design. Trials 2013 14(Suppl 1):P15.
Submit your next manuscript to BioMed Central and take full advantage of:

- Convenient online submission

- Thorough peer review

- No space constraints or color figure charges

- Immediate publication on acceptance

- Inclusion in PubMed, CAS, Scopus and Google Scholar

- Research which is freely available for redistribution
() Bïomed Central (c) 2013 Hemming and Girling; licensee BioMed Central Ltd. This is an Open Access article distributed under the terms of the Creativ Commons Attribution License (http://creativecommons.org/licenses/by/2.0), which permits unrestricted use, distribution, and reproduction in any medium, provided the original work is properly cited. 